\title{
Czy mastektomia z rekonstrukcją natychmiastową piersi stanowi alternatywę dla leczenia oszczędzającego pierś?
}

\author{
Piotr Pluta, Janusz Piekarski
}

Mimo że leczenie oszczędzające pierś uznawane jest za metodę z wyboru w leczeniu chorych na wczesnego raka piersi, w niektórych badaniach zaobserwowano wzrost częstości wykonywanych mastektomii. Coraz częściej w trakcie mastektomii wykonywana jest natychmiastowa rekonstrukcja piersi, mająca na celu zmniejszenie okaleczenia związanego z utratą piersi. Wykazano, że zarówno leczenie oszczędzające pierś, jak i mastektomia z natychmiastową rekonstrukcją piersi są zabiegami bezpiecznymi onkologicznie i przynoszą porównywalny komfort życia. Jednak zabieg mastektomii z rekonstrukcją natychmiastową piersi jest obarczony większym odsetkiem powikłań pooperacyjnych, zwłaszcza w przypadku zastosowania radioterapii uzupełniającej. Dodatkową korzyścią leczenia oszczędzającego pierś jest możliwość odstąpienia od wykonania limfadenektomii pachowej w przypadku przerzutów ograniczonych do 1-2 węzłów wartowniczych, przez co chore mogą uniknąć powikłań związanych z usunięciem węzłów chłonnych pachowych. Ustalając plan leczenia chorych, należy zwrócić uwagę na potencjalną przewagę, jaką posiada leczenie oszczędzające pierś, nad mastektomią z rekonstrukcją natychmiastową pod względem ryzyka wystąpienia powikłań.

\section{Is mastectomy with immediate breast reconstruction an alternative to breast-conserving treatment?}

Beside the fact that breast-conserving treatment is the method of choice in early breast cancer, several studies have demonstrated good results when mastectomy is involved in the treatment. Such studies are currently increasing. Immediate breast reconstruction is gaining popularity as the method that mitigates post-mastectomy deformation. Comparing breast-conserving treatment and immediate breast reconstruction after mastectomy both methods did not worsen the treatment outcome and have a positive impact to quality of life. However, the complications rate is higher after mastectomy with immediate breast reconstruction, especially in the subgroup of patients receiving postmastectomy radiotherapy. Breast-conserving therapy additionally gives the opportunity to avoid axillary lymph nodes dissection in the subgroup of patients with positive 1-2 sentinel nodes. It should be taken into consideration when a treatment schedule is established, that breast-conserving therapy has an advantage regarding risk of complications.

NOWOTWORY J Oncol 2016; 66, 3: 216-221

Słowa kluczowe: rak piersi, mastektomia, natychmiastowa rekonstrukcja piersi, leczenie oszczędzające pierś Key words: breast cancer, mastectomy, immediate breast reconstruction, breast-conservation

\section{Wstęp}

Do połowy lat osiemdziesiątych ubiegłego wieku chore na miejscowo zaawansowanego raka piersi miały wykonywaną mastektomię. Przedstawienie wyników badań przez
Umberto Veronesiego, a następnie Bernarda Fishera pozwoliły na wprowadzenie leczenia oszczędzającego pierś, obejmującego wycięcie guza z następową radioterapią jako alternatywę dla mastektomii [1, 2]. Obecnie leczenie oszczę-

Klinika Chirurgii Onkologicznej UM w Lodzi

II Oddział Chirurgii Onkologicznej

WSS im. M. Kopernika w Łodzi 
dzające pierś uznawane jest za leczenie z wyboru u chorych na wczesnego raka piersi a wykonanie mastektomii winno być rozpatrywane w przypadku przeciwwskazań do jego wdrożenia [3, 4]. Jak wykazano na podstawie danych 15369 chorych na wczesnego raka piersi zebranych z 23 europejskich ośrodków, w latach 2003-2010 leczenie oszczędzające pierś zastosowano u $78 \%$ chorych, a odsetek mastektomii zmniejszał się rocznie o 4,24\% [5].

W przeciwieństwie do badań europejskich w Stanach Zjednoczonych w 2009 roku zaobserwowano trend dla wzrostu odsetka mastektomii $[6,7]$. Obserwację tę potwierdzono również na dużej grupie chorych, poddając analizie dane z bazy SEER (Surveillance, Epidemiology, and End Results), obejmujące $1 / 4$ populacji kobiet chorych na raka piersi w Stanach Zjednoczonych [8]. W latach 2000-2008 spośród 256 tys. kobiet leczonych z powodu raka piersi zabieg mastektomii wykonano u $37 \%$ chorych, a u $61 \%$ zastosowano leczenie oszczędzające pierś. Mimo że odsetek mastektomii pomiędzy rokiem 2000 a 2005 zmniejszył się z 40\% do 36\%, to następnie zwiększył się do 38\% w 2008 roku. W innym badaniu zwrócono uwagę na wzrost odsetka obustronnych mastektomii u chorych na wczesnego raka piersi, u których oprócz mastektomii terapeutycznej wykonano profilaktyczną mastektomię piersi kontralateralnej i rekonstrukcję obu piersi [9].

Istnieje kilka możliwych przyczyn zwiększonego odsetka mastektomii. Wprowadzenie rezonansu magnetycznego do diagnostyki chorób piersi zwiększa liczbę wykrywanych zmian potencjalnie patologicznych poza ogniskiem pierwotnym [10]. To z kolei wpływa na wzrost liczby biopsji zmian w piersi, a jednocześnie wywołuje opór pacjentek przed leczeniem oszczędzającym.

Kolejną przyczyną obserwowanego wzrostu odsetka mastektomii może być zwiększenie zainteresowania przez pacjentów badaniami genetycznych i tym samym częstszym wykrywaniem mutacji BRCA1/2 [11]. Pomimo niejednoznacznych doniesień dotyczących przewagi mastektomii nad leczeniem oszczędzającym pierś u nosicielek mutacji BRCA1/2, u których wykryto raka piersi, w tej grupie chorych mastektomia pozostaje metodą z wyboru $[12,13]$. Ponadto poszerzenie leczenia chirurgicznego o wykonanie mastektomii profilaktycznej piersi kontralateralnej może mieć u nich korzystny wpływ na przeżycie $[14,15]$. Wykonanie obustronnej mastektomii w przypadku chorych na raka piersi obciążonych mutacją BRCA1/2 jest uzasadnione również ekonomicznie, niosąc za sobą mniejsze koszty niż chemoprewencja i ścisła obserwacja pod kątem zachorowania na raka drugiej piersi [16].

Ważną rolę odgrywają preferencje chorej odnośnie metody leczenia, jak i sposób komunikacji między chirurgiem a pacjentką. Zaobserwowano, że chore bardziej zaangażowane w proces decyzyjny częściej decydowały się na mastektomię [17]. W badaniu Morrow i wsp. około 1/3 cho- rych na raka piersi zdecydowała się na mastektomię, kiedy przedstawiono im leczenie oszczędzające i mastektomię jako metody równoważne. W przypadku rekomendowania przez chirurga leczenia oszczędzającego pierś jedynie $2 \%$ chorych wybrało mastektomię wbrew jego opinii. Chore niegodzące się na leczenie oszczędzające pierś przeważnie zgłaszają obawę przed nawrotem choroby, poczucie lepszego rokowania po mastektomii oraz chęć uniknięcia radioterapii [18-20]. Wykazano również, że dostęp do zabiegów rekonstrukcji piersi zwiększał częstość decyzji kobiet o poddaniu się mastektomii [21].

Utrata piersi w wyniku mastektomii może negatywnie wpływać na psychikę chorych, przyczyniając się do rozwoju objawów depresji, trudności w odbiorze własnego ciała oraz spadku zadowolenia w sferze seksualnej [22]. W celu zachowania komfortu życia coraz częściej wykonywane są mastektomie z natychmiastową rekonstrukcją piersi z wykorzystaniem ekspanderów i implantów lub rzadziej — tkanek własnych [23, 24]. W niniejszym opracowaniu podjęto próbę odpowiedzi na pytanie, czy zabieg mastektomii z natychmiastową rekonstrukcją piersi może stanowić alternatywę dla leczenia oszczędzającego pierś.

\section{Wyniki leczenia po leczeniu oszczędzającym pierś i po mastektomii z rekonstrukcją piersi}

Jednym z kluczowych zagadnień dotyczących mastektomii z natychmiastową rekonstrukcją piersi u chorych na raka piesi jest bezpieczeństwo onkologiczne. Skuteczne leczenie onkologiczne wymaga zachowania reżimu czasowego dla wdrożenia leczenia uzupełniającego. W badaniu Dogana i wsp. nie stwierdzono różnic w czasie rozpoczęcia chemioterapii i radioterapii uzupełniającej pomiędzy zabiegami oszczędzającymi pierś (lumpektomie i resekcje onkoplastyczne) a mastektomiami [25]. W odniesieniu do mastektomii z rekonstrukcją, w metaanalizie obejmującej 14 badań klinicznych również nie wykazano istotnej różnicy pomiędzy czasem wdrożenie chemioterapii po mastektomiach z natychmiastową rekonstrukcją piersi w porównaniu z samą mastektomią [26]. Nie zaobserwowano także, aby wykonanie mastektomii $z$ natychmiastową rekonstrukcją piersi z wykorzystaniem ekspanderów i implantów (zabiegi dwuetapowe) miało wpływ na opóźnienie wdrożenia radioterapii uzupełniającej [27-29]. Kwalifikując chore do rekonstrukcji piersi, ważne jest jednak, aby zabieg ten był skoordynowany z całym planem leczenia i omówiony w zespole wielodyscyplinarnym przed jego rozpoczęciem.

W odniesieniu do wyników odległych po mastektomiach z rekonstrukcją piersi nie stwierdzono negatywnego wpływu na czas przeżycia chorych [30-32]. W badaniu Platt i wsp. ocenie poddano wpływ wykonania rekonstrukcji piersi na wyniki leczenia w obserwacjach 20-letnich [30]. Analizowano dane Ontario Cancer Registry kobiet leczonych w latach 1980-1990. Porównano wyniki leczenia chorych 
na raka piersi, u których wykonano rekonstrukcję piersi do 5 lat od mastektomii, z chorymi, u których po mastektomii piersi nie odtworzono. Wyłoniono 785 par kobiet, dobranych zgodnie $z$ wiekiem i stopniem zaawansowania choroby. W badaniu tym wykazano, że wykonanie rekonstrukcji piersi wiązało się ze zmniejszeniem ryzyka zgonu o 17\% i zgonu zależnego od choroby nowotworowej o 19\%. Autorzy publikacji zwracają uwagę, że w chwili obecnej brak biologicznego wytłumaczenia tego fenomenu iże obserwacja ta może być wynikiem kwalifikowania do rekonstrukcji piersi chorych będących w lepszym stanie ogólnym lub o wyższym statusie socjoekonomicznym. Jednak badanie to potwierdza, że rekonstrukcja piersi nie pogarsza wyników leczenia chorych na raka piersi.

Bezpieczeństwo onkologiczne leczenia oszczędzającego pierś zostało potwierdzone $w$ licznych badaniach klinicznych [33-35]. W 2012 roku opublikowano wyniki wieloośrodkowego randomizowanego badania EORTC 10801, w którym oceniono 20-letnie przeżycia chorych po leczeniu oszczędzającym pierś i po mastektomii [35]. W badaniu przeprowadzonym na grupie ponad 860 chorych wykazano, że odległe przeżycia chorych po leczeniu oszczędzającymi pierś i po mastektomii nie różnią się statystycznie (20-letnie całkowite przeżycia chorych wynosiły odpowiednio 39\% i 44\%). W analizie 10-letniej tego badania wykazano natomiast zwiększone ryzyko nawrotu miejscowego po leczeniu oszczędzającym pierś w porównaniu z mastektomią (odpowiednio $20 \%$ i $12 \%$ ). W innych badaniach nie potwierdzono, aby odsetki nawrotów miejscowych po leczeniu oszczędzającym i po mastektomii różniły się istotnie [36, 37]. Zaobserwowano również, że przeżycia zależne od nowotworu u chorych na raka piersi mogą być lepsze w przypadku zastosowania leczenia oszczędzającego pierś w porównaniu z mastektomią i mastektomią z uzupełniającą radioterapią [38].

Należy zatem uznać, że wykonanie mastektomii z natychmiastową rekonstrukcją piersi, jak i zabiegu oszczędzającego pierś jest równie bezpieczne, gdyż metody te nie opóźniają optymalnego czasu dla wdrożenia leczenia uzupełniającego. W chwili obecnej nie wykazano przewagi w wynikach leczenia żadnej z metod, jednak problem ten powinien być tematem przyszłych badań prospektywnych.

\section{Ryzyko powikłań i komfort życia po leczeniu oszczędzającym pierś i po mastektomii z rekonstrukcją piersi}

Zgodnie z definicją zdrowie to nie tylko brak choroby, ale całościowy dobrostan fizyczny, psychiczny i społeczny [39]. Przy porównywalnych wynikach odległych leczenia oszczędzającego pierś i mastektomii jednym z kluczowych czynników mogących wpłynąć na podjęcie decyzji o rodzaju leczenia staje się jakość życia i ryzyko wystąpienia powikłań.
W 2015 roku ukazała się publikacja, której autorzy ocenili ryzyko powikłań pooperacyjnych u chorych po leczeniu oszczędzającym pierś (9571 chorych) i w grupie po mastektomii z jednoczasową rekonstrukcją piersi z użyciem implantów (2074 chore) [40]. Porównując częstość występowania chorób towarzyszących, stwierdzono, że do zabiegów oszczędzających pierś częściej kwalifikowane były chore z nadciśnieniem, chorobą niedokrwienną serca, przewlekłą obturacyjną chorobą płuc i cukrzycą. Były to chore w starszym wieku (mediana wieku w grupie chorych po zabiegu oszczędzającym pierś i w grupie z mastektomią połączoną z rekonstrukcją wyniosła odpowiednio 61,7 i 53,5 roku) i z wyższym wskaźnikiem masy ciała. Pomimo niekorzystnych cech ogólnoustrojowych pacjentek, mogących negatywnie wpłynąć na przebieg pooperacyjny, stwierdzono, że odsetek powikłań po zabiegu oszczędzającym pierś był niższy niż w grupie chorych po mastektomii z natychmiastową rekonstrukcją piersi. Łączny odsetek powikłań w grupie po leczeniu oszczędzającym i po mastektomii z rekonstrukcją piersi wynosił odpowiednio: 2,1 i 5,5\%; częstość infekcji: 0,4 i 1,9\%; krwawień do rany 0,05\% i 0,2\%. Badanie to wskazuje, że mastektomia z rekonstrukcją piersi wiąże się z wyższym ryzykiem powikłań pooperacyjnych w porównaniu z zabiegiem oszczędzającym pierś.

Pomimo niejednoznacznych wyników badań uważa się, że główna przewaga leczenia oszczędzającego pierś nad mastektomią związana jest z lepszym efektem kosmetycznym oraz mniejszym urazem psychicznym i emocjonalnym po leczeniu oszczędzającym [33, 34, 41-44]. W badaniu Parker i wsp. porównano jakość życia fizycznego i psychicznego oraz objawy przystosowawcze (m.in. ocena poziomu lęku, seksualności, wyglądu klatki piersiowej, zadowolenia z sylwetki) w zależności od sposobu leczenia u 258 chorych na raka piersi [41]. Wyodrębniono 3 grupy chorych: chore po leczeniu oszczędzającym, po mastektomii i mastektomii $z$ rekonstrukcją piersi. Badane chore wypełniały ankiety dotyczące poruszanych aspektów jakości życia po 1, 6, 12 i 24 miesiącach po zabiegu. Stwierdzono, że różnice przystosowawcze różnią się pomiędzy grupami do 24 miesięcy od zabiegu. W grupie chorych po zabiegu oszczędzającym stwierdzono większe zadowolenie z wyglądu klatki piersiowej i wyższą jakość zdrowia fizycznego. Po dwóch latach od zabiegu większość objawów przystosowawczych i jakość życia powróciła do poziomu przed zabiegiem. Badanie to nie wykazało, aby rodzaj leczenia miał bezwzględny wpływ na jakość życia, dlatego decyzja o metodzie leczenia powinna być podjęta z czynnym udziałem chorego z uwzględnieniem jego oczekiwań i obaw.

Odmienne wyniki uzyskano w badaniu Jagsi i wsp., w którym 9 miesięcy i 4 lata od rozpoznania ocenie poddano komfort życia 1450 chorych operowanych z powodu raka piersi [43]. Zaobserwowano porównywalny komfort życia po leczeniu oszczędzającym pierś i po mastektomii 
z rekonstrukcją piersi oraz istotnie niższy u kobiet po mastektomii bez rekonstrukcji. Analizując technikę rekonstrukcji piersi, stwierdzono wyższy poziom satysfakcji w przypadku rekonstrukcji piersi za pomocą tkanek własnych niż w przypadku rekonstrukcji piersi materiałami syntetycznymi. Zaobserwowano również istotny wpływ na obniżenie poziomu satysfakcji w przypadku kobiet, u których zastosowano napromieniania piersi, zwłaszcza w grupie po rekonstrukcji piersi z użyciem implantów.

Radioterapia uzupełniająca stanowi istotny problem wprzypadku wykonania natychmiastowej rekonstrukcji piersi, mogący zniweczyć efekt kosmetyczny zabiegu. Do powikłań po rekonstrukcjach piersi i radioterapii należą zaburzenia gojenia rany, powstawanie nieestetycznych blizn i torebek włóknistych deformujących kształt odtwarzanej piersi, infekcje rany, martwica płatów skórnych z odsłonięciem implantu oraz nasilony ból miejsca operowanego $[45,46]$. Z kolei zastosowanie tkanek własnych do rekonstrukcji piersi w przypadku radioterapii częściej doprowadza do deformacji płatów na skutek włóknienia, martwicy i obkurczania się tkanek [47, 48]. W metaanalizie obejmującej 11 badań na łącznej grupie 1105 chorych potwierdzono, że zastosowanie radioterapii zwiększa ryzyko powikłań pooperacyjnych po natychmiastowej rekonstrukcji piersi, przy czym częściej występują one w grupie chorych, u których zastosowano implant, niż w przypadku chorych po rekonstrukcjach piersi z tkanek własnych [49]. Niemniej jednak w niektórych ośrodkach uzyskiwano wysoki stopień satysfakcji chorych po wykonaniu rekonstrukcji piersi z zastosowaniem ekspanderów i implantów pomimo napromieniania uzupełniającego, co wskazuje na wpływ doświadczenia zespołów leczących zwłaszcza w przypadku leczenia skojarzonego [28, 50].

Ważną opcją leczenia chorych z miejscowo zaawansowanym rakiem piersi jest możliwość zastosowania chemioterapii neoadiuwantowej. Zastosowanie chemioterapii przedoperacyjnej poprzez zmniejszenie wielkości ogniska pierwotnego ułatwia wykonanie zabiegu oszczędzającego pierś [51]. W badaniu Cho i wsp. wykazano, że odsetek nawrotów miejscowych, przeżycia wolne od choroby i przeżycia odległe były takie same w przypadku zastosowania leczenia oszczędzającego i mastektomii [52]. Warunkiem wykonania zabiegu oszczędzającego pierś jest dobra odpowiedź kliniczna i radiologiczna na chemioterapię. Ocena powikłań pooperacyjnych u chorych na raka piersi po chemioterapii była przedmiotem badania Garveya i wsp. [53]. Analizą objęto 148 chorych, u których wykonano zabieg oszczędzający pierś, mastektomię oraz mastektomię z rekonstrukcją natychmiastową lub odroczoną. Łącznie odsetek powikłań w gojeniu stwierdzono u 34\%, przy czym powikłania poważne, tj. wymagające ponownej interwencji chirurgicznej - u 18\%. U żadnej chorej, u której wykonano zabieg oszczędzający pierś, nie stwierdzono wskazań do reoperacji, i powikłania mogły być leczone zachowawczo.
Z kolei w badaniu Decker i wsp. nie stwierdzono różnic w odsetku powikłań w gojeniu rany pomiędzy chorymi na raka piersi operowanymi po zastosowaniu chemioterapii neoadiuwantowej i bez chemioterapii [54]. Autorzy tego badania wskazują na trend dla większego odsetka powikłań po mastektomii z rekonstrukcją natychmiastową piersi. W świetle tych badań w przypadku mastektomii z rekonstrukcją natychmiastową należy zwrócić uwagę na zwiększone ryzyko powikłań pooperacyjnych.

Należy również zwrócić uwagę na fakt, że leczenie oszczędzające nie zawsze przynosi zadawalające efekty kosmetyczne i wysoki komfort życia, co może być związane zarówno z techniką zabiegu, jak i radioterapią uzupełniającą. W 2012 roku przedstawiono badanie Hill-Kayser i wsp. przeprowadzone w grupie 354 chorych, u których zastosowano zabieg oszczędzający pierś i radioterapię uzupełniającą [55]. Stwierdzono w nim, że 30\% chorych ocenia efekt kosmetyczny leczenia jako średni lub słaby. Ponadto ponad połowa chorych skarżyła się na zaburzenia poznawcze i problemy seksualne. Chore zgłaszały również zmiany w zabarwieniu skóry, przewlekły ból i zaburzenia czucia skóry piersi oraz utratę miękkości piersi. Wśród zmian ogólnoustrojowych, które chore wiązały z zastosowanym leczeniem, opisano wystąpienie osteoporozy i osteopenii, chorób układu krążenia i układu oddechowego oraz obrzęk limfatyczny. W aspekcie zadowolenia z uzyskanego efektu kosmetycznego kluczowe może być stosowanie technik onkoplastycznych mających na celu zachowanie obrysu piersi przy usuwaniu większych lub niekorzystnie położonych guzów piersi $[56,57]$.

Analizując komfort życia i możliwe powikłania związane z leczeniem, należy zwrócić uwagę na nowe zalecenia dotyczące postępowania u chorych, u których zastosowano leczenie oszczędzające pierś i stwierdzono przerzuty do węzłów wartowniczych $[3,4]$. Na podstawie wyników badania ACOSOG Z0011 przedstawionego przez Giuliana i wsp. w przypadku obecności przerzutów ograniczonych do 1 lub 2 węzłów chłonnych możliwe jest odstąpienie od limfadenektomii pachowej, o ile zastosowana będzie radioterapia uzupełniająca z pól tangencjalnych obejmujących całą pierś [58,59]. Obecnie wykonanie mastektomii z rekonstrukcją piersi nie pozwala na odstąpienie od usunięcia węzłów chłonnych pachowych w przypadku ograniczonych przerzutów do węzła wartowniczego. Być może wieloośrodkowe badanie randomizowane BOOG 2013-07 wykaże, że również w tej grupie u wybranych chorych będzie możliwe odstąpienie od limfadenektomii pachowej [60]. W 43 ośrodkach w Holandii trwa rekrutacja chorych z naciekającym rakiem piersi w stopniu T1-2N0, którzy w przypadku przerzutów do 1-3 węzłów chłonnych wartowniczych są randomizowani do dalszej obserwacji lub do leczenia w obrębie jamy pachowej (limfadenekomia pachowa lub napromienianie na okolicę pachową i nadobojczykową). Istotną cechą tego badania 
jest precyzyjna ocena ultrasonograficzna stanu węzłów chłonnych w momencie rozpoznania choroby. Analizowane będą wyniki leczenia pod kątem ryzyka nawrotów regionalnych, a także m.in. czasów przeżycia chorych i jakości życia w obserwacjach 5-i 10-letnich. W chwili obecnej podkreślić jednak należy, że w wyselekcjonowanej grupie chorych z przerzutami do węzłów wartowniczych leczenie oszczędzające pierś ma przewagę nad mastektomią z rekonstrukcją piersi pod względem możliwości uniknięcia powikłań związanych z limfadenektomią pachową.

\section{Podsumowanie}

Leczenie oszczędzające pierś i mastektomia z rekonstrukcją piersi są metodami równie bezpiecznymi onkologicznie. Ryzyko wystąpienia powikłań pooperacyjnych zarówno u chorych pierwotnie operowanych, jak i operowanych po zakończeniu chemioterapii neoadiuwantowej jest wyższe w przypadku wykonania mastektomii z natychmiastową rekonstrukcją piersi w porównaniu z zabiegiem oszczędzającym pierś. Radioterapia pooperacyjna jest ważnym czynnikiem ryzyka niesatysfakcjonującego efektu kosmetycznego w przypadku wykonania mastektomii z rekonstrukcją natychmiastową piersi. Leczenie oszczędzające pierś pozwala na zachowanie węzłów chłonnych pachowych u wybranych chorych z przerzutami do węzła wartowniczego. Leczenie oszczędzające pierś winno zatem pozostać metodą z wyboru u chorych z miejscowo zaawansowanym rakiem piersi. U większości chorych na raka piersi, u których występują przeciwwskazania do leczenia oszczędzającego pierś, mastektomia z natychmiastową rekonstrukcją piersi jest bezpieczną alternatywą dla samej mastektomii.

\section{Konflikt interesów: nie zgłoszono}

\section{Dr n. med. Piotr Pluta}

Klinika Chirurgii Onkologicznej UM w Łodzi

II Oddział Chirurgii Onkologicznej

WSS im. M. Kopernika w Łodzi

ul. Pabianicka 62, 93-513 Łódź

e-mail:piotr.pluta@umed.lodz.pl

Otrzymano: 28 grudnia 2015 r.

Przyjęto do druku: 2 lutego $2016 r$.

\section{Piśmiennictwo}

1. Veronesi U, Cascinelli N, Mariani L i wsp. Twenty-year follow-up of a randomized study comparing breast-conserving surgery with radical mastectomy for early breast cancer. NEngl J Med 2002; 347: 1227-1232.

2. Fisher B, Anderson S, Bryant Ji iwsp. Twenty-year follow-up of a randomized trial comparing total mastectomy, lumpectomy, and lumpectomy plus irradiation for the treatment of invasive breast cancer. NEngl JMed 2002; 347: 1233-1241.

3. http://www.onkologia.zalecenia.med.pl/pdf/PTOK_2013_05_Rak\%20 piersii.pdf.

4. http://www.nccn.org/professionals/physician gls/pdf/breast.pdf

5. Garcia-Etienne CA, Tomatis M, Heil J i wsp. Mastectomy trends for early-stage breast cancer: a report from the EUSOMA multi-institutional European database. Eur J Cancer 2012; 48: 1947-1956.
6. Katipamula R, Degnim AC, Hoskin T i wsp. Trends in mastectomy rates at the Mayo Clinic Rochester: effect of surgical year and preoperative magnetic resonance imaging. J Clin Oncol 2009; 27: 4082-4088.

7. McGuire KP, Santillan AA, Kaur P i wsp. Are mastectomies on the rise? A 13-year trend analysis of the selection of mastectomy versus breast conservation therapy in 5865 patients. Ann Surg Oncol 2009; 16: 2682-2690.

8. Mahmood U, Hanlon AL,Koshy Mi wsp. Increasing national mastectomy rates for the treatment of early stage breast cancer. Ann Surg Oncol 2013; 20: 1436-1443.

9. Albornoz CR, Matros E, Lee CN i wsp. Bilateral mastectomy versus breast-conserving surgery for early-stage breast cancer: the role of breast reconstruction. Plast Reconstr Surg 2015; 135: 1518-1526.

10. Houssami N, Turner R, Morrow M. Preoperative magnetic resonance imaging in breast cancer: meta-analysis of surgical outcomes. Annals of Surgery 2013; 257: 249-255.

11. Evans DG, Barwell J, Eccles DM i wsp. The Angelina Jolie effect: how high celebrity profile can have a major impact on provision of cancer related services. Breast Cancer Res 2014; 16: 442.

12. Valachis $A$, Nearchou AD, Lind P. Surgical management of breast cance in BRCA-mutation carriers: a systematic review and meta-analysis. Breast Cancer Research and Treatment 2014; 144: 443-455.

13. Hallam S, Govindarajulu S, Huckett, B i wsp. A. BRCA1/2 Mutation-associated Breast Cancer, Wide Local Excision and Radiotherapy or Unilateral Mastectomy: A Systematic Review. Clinical Oncology 2015; 27: 527-535.

14. Evans DG, Ingham SL, Baildam A i wsp. Contralateral mastectomy improves survival in women with BRCA1/2-associated breast cancer. Breast Cancer Research and Treatment 2013; 140; 135-142.

15. Metcalfe K, Gershman S, Ghadirian P i wsp. Contralateral mastectomy and survival after breast cancer in carriers of BRCA1 and BRCA2 mutations: retrospective analysis. BMJ 2014; 348: 226-226.

16. Grann VR, Patel PR, Jacobson JS i wsp. Comparative effectiveness of screening and prevention strategies among BRCA1/2-affected mutation carriers. Breast Cancer Res Treat 2011; 125: 837-847.

17. Morrow $M$, Jagsi $R$, Alderman AK i wsp. Surgeon recommendations and receipt of mastectomy for treatment of breast cancer. JAMA 2009; 302: 1551-1556.

18. Katz SJ, Lantz PM, Janz NK i wsp. Patient involvement in surgery treatment decisions for breast cancer. J Clin Oncol 2005; 23: 5526-5533.

19. Hawley ST, Griggs JJ, Hamilton AS i wsp. Decision involvement and receipt of mastectomy among racially and ethnically diverse breast cancer patients. JNCI 2009; 101: 1337-1347.

20. Fisher CS, Martin-Dunlap T, Ruppel MB i wsp. Fear of recurrence and perceived survival benefit are primary motivators for choosing mastectomy over breast-conservation therapy regardless of age. Annals of Surgical Oncology 2012; 19: 3246-3250.

21. Alderman AK, Hawley ST, Waljee J i wsp. Understanding the impact of breast reconstruction on the surgical decision-making process for breast cancer. Cancer 2008; 112: 489-494.

22. Kamińska M, Kubiatowski T, Ciszewski T i wsp. Evaluation of symptoms of anxiety and depression in women with breast cancer after breast amputation or conservation treated with adjuvant chemotherapy. Ann Agric Environ Med 2015; 22: 185-189.

23. Albornoz CR, Bach PB, Mehrara BJ, Disa JJ i wsp. A paradigm shift in U.S. Breast reconstruction: increasing implant rates. Plast Reconstr Surg 2013; 131: 15-23.

24. Albornoz CR, Cordeiro PG, Pusic AL i wsp. Diminishing relative contraindications for immediate breast reconstruction: a multicenter study. $J$ Am Coll Surg 2014; 219: 788-795.

25. Dogan L, Gulcelik MA, Karaman N i wsp. Oncoplastic surgery in surgical treatment of breast cancer: is the timing of adjuvant treatment affected? Clin Breast Cancer 2013; 13: 202-205.

26. Xavier Harmeling J, Kouwenberg CA, Bijlard E i wsp. The effect of immediate breast reconstruction on the timing of adjuvant chemotherapy: a systematic review. Breast Cancer Res Treat 2015; 153: 241-251.

27. Cordeiro PG, Albornoz CR, McCormick B i wsp.. What is the optimum timing of postmastectomy radiotherapy in two-stage prosthetic reconstruction: radiation to the tissue expander or permanent implant? Plast Reconstr Surg 2015; 135: 1509-1517.

28. Cordeiro PG, Albornoz CR, McCormick B i wsp. The impact postmastectomy radiotherapy on two-stage implant breast reconstruction: an analysis of long-term surgical outcomes, aesthetic results, and satisfaction over 13 years. Plast Reconstr Surg 2014; 134: 588-595.

29. Ho A, Cordeiro P, Disa J i wsp. Long-term outcomes in breast cancer patients undergoing immediate 2-stage expander/implant reconstruction and postmastectomy radiation. Cancer 2012; 118: 2552-2559. 
30. Platt J, Baxter NN, McLaughlin J i wsp. Does breast reconstruction after mastectomy for breast cancer affect overall survival? Long-term follow-up of a retrospective population-based cohort. Plast Reconstr Surg 2015; 135: 468e-476e.

31. Bezuhly M, Temple C, Sigurdson LJ i wsp. Immediate postmastectomy reconstruction is associated with improved breast cancer-specific survival: evidence and new challenges from the Surveillance, Epidemiology, and End Results database. Cancer 2009; 115: 4648-4654.

32. Hölmich LR, Düring M, Henriksen TF i wsp. Delayed breast reconstruction with implants after invasive breast cancer does not impair prognosis. Ann Plast Surg 2008; 61: 11-18.

33. Veronesi U, Cascinelli N, Mariani L i wsp. Twenty-year follow-up of a randomized study comparing breast-conserving surgery with radical mastectomy for early breast cancer. NEng/ J Med 2002; 347: 1227-1232.

34. Fisher B, Anderson S, Bryant J i wsp. Twenty-year follow-up of a randomized trial comparing total mastectomy, lumpectomy, and lumpectomy plus irradiation for the treatment of invasive breast cancer. NEngl JMed 2002; 347: 1233-1241.

35. Litière $S$, Werutsky $G$, Fentiman IS i wsp.. Breast conserving therapy versus mastectomy for stage I- II breast cancer: 20 year follow-up of the EORTC 10801 phase 3 randomised trial. Lancet Oncol 2012; 13:412-419.

36. Anderson SJ, Wapnir I, Dignam JJ i wsp. Prognosis after ipsilateral breast tumor recurrence and locoregional recurrences in patients treated by breast-conserving therapy in five National Surgical Adjuvant Breast and Bowel Project protocols of node-negative breast cancer. J Clin Oncol 2009; 27: 2466-2473.

37. Zumsteg ZS, Morrow M, Arnold B i wsp. Breast-conserving therapy achieves locoregional outcomes comparable to mastectomy in women with T1-2N0 triple-negative breast cancer. Ann Surg Oncol 2013; 20:3469-3476.

38. Agarwal S, Pappas L, Neumayer L i wsp. Effect of breast conservation therapy vs mastectomy on disease-specific survival for early-stage breast cancer. JAMA Surg 2014; 149: 267-274.

39. Preamble to the Constitution of the World Health Organization as adopted by the International Health Conference, New York, 19-22 June, 1946; signed on 22 July 1946 by the representatives of 61 States (Official Records of the World Health Organization, no. 2, p. 100) and entered into force on 7 April 1948.

40. Pyfer B, Chatterjee A, Chen L i wsp. Early postoperative outcomes in breast conservation surgery versus simple mastectomy with implant reconstruction: a NSQIP analysis of 11,645 patients. Ann Surg Oncol 2016; 23: 92-98.

41. Parker PA, Youssef A, Walker Si wsp. Short-term and long-term psychosocial adjustment and quality of life in women undergoing different surgical procedures for breast cancer. Ann Surg Oncol 2007; 14: 3078-3089.

42. He ZY, Tong $Q$, Wu SG i wsp. A comparison of quality of life and satisfaction of women with early-stage breast cancer treated with breast conserving therapy vs. mastectomy in southern China. Support Care Cancer 2012; 20: 2441-2449.

43. Jagsi R, Li Y, Morrow M i wsp. Patient-reported quality of life and satisfaction with cosmetic outcomes after breast conservation and mastectomy with and without reconstruction: results of a survey of breast cancer survivors. Ann Surg 2015; 261: 1198-1206.

44. Sun Y, Kim SW, Heo CY i wsp. Comparison of quality of life based on surgical technique in patients with breast cancer. Jpn J Clin Oncol 2014; 44: 22-27.
45. Tallet AV, Salem N, Moutardier V i wsp. Radiotherapy and immediate two-stage breast reconstruction with a tissue expander and implant: complications and esthetic results. Int J Radiat Oncol Biol Phys 2003; 57: 136-142.

46. Ascherman JA, Hanasono MM, Newman MI i wsp. Implant reconstruction in breast cancer patients treated with radiation therapy. Plast Reconstr Surg 2006; 117: 359-365.

47. Williams JK, Carlson GW, Bostwick J i wsp. The effects of radiation treatment after TRAM flap breast reconstruction. Plast Reconstr Surg. 1997; 100: 1153- 1160.

48. Rogers NE, Allen RJ. Radiation effects on breast reconstruction with the deep inferior epigastric perforator flap. Plast Reconstr Surg 2002; 109: 1919-1924.

49. Barry M, Kell MR. Radiotherapy and breast reconstruction: a meta-analysis. Breast Cancer Res Treat 2011; 127: 15-22.

50. Ribuffo D, Atzeni M, Guerra M i wsp. Treatment of irradiated expanders: protective lipofilling allows immediate prosthetic breast reconstruction in the setting of postoperative radiotherapy. Aesthetic Plast Surg 2013; 37: 1146-1152.

51. Fitzal F, Riedl O, Mittlböck M i wsp. Oncologic safety of breast conserving surgery after tumour downsizing by neoadjuvant therapy: a retrospective single centre cohort study. Breast Cancer Research and Treatment 2011; 127: 121-128.

52. Cho JH, Park JM, Park HS i wsp. Oncologic safety of breast-conserving surgery compared to mastectomy in patients receiving neoadjuvant chemotherapy for locally advanced breast cancer. J Surg Oncol 2013; 108: 531-536.

53. Garvey EM, Gray RJ, Wasif N i wsp. Neoadjuvant therapy and breast cancer surgery: a closer look at postoperative complications. Am J Surg 2013; 206: 894-899.

54. Decker MR, Greenblatt DY, Havlena J i wsp. Impact of neoadjuvant chemotherapy on wound complications after breast surgery. Surgery 2012; 152: 382-388.

55. Hill-Kayser CE, Vachani C, Hampshire MK i wsp Cosmetic outcomes and complications reported by patients having undergone breast-conserving treatment. Int J Radiat Oncol Biol Phys 2012; 83: 839$-844$.

56. Veiga DF, Veiga-Filho J, Ribeiro LM i wsp. Quality-of-life and self-esteem outcomes after oncoplastic breast-conserving surgery. Plast Reconstr Surg 2010; 125: 811-817.

57. Maguire PD, Adams A, Nichols MA. Oncoplastic surgery and radiation therapy for breast conservation: early outcomes. Am J Clin Oncol 2015; 38: 353-357.

58. Giuliano AE, McCall L, Beitsch P i wsp. Locoregional recurrence after sentinel lymph node dissection with or without axillary dissection in patients with sentinel lymph node metastases: the American College of Surgeons Oncology Group Z0011 randomized trial. Ann Surg 2010; 252: 426-432.

59. Giuliano AE, Hunt KK, Ballman KV i wsp. Axillary dissection vs no axillary dissection in women with invasive breast cancer and sentinel node metastasis: a randomized trial. JAMA 2011; 305: 569-575.

60. van Roozendaal LM, de Wilt JH, van Dalen T i wsp. The value of completion axillary treatment in sentinel node positive breast cancer patients undergoing a mastectomy: a Dutch randomized controlled multicentre trial (BOOG 2013-07). BMC Cancer 2015; 15: 610 